\title{
Peningkatan motivasi membaca permulaan melalui metode scramble kalimat pada siswa Kelas 2 SDN Pandeyan Yogyakarta
}

\author{
Octavian Muning Sayekti* \\ Pendidikan Sekolah Dasar, Universitas Negeri Yogyakarta \\ *Corresponding Author. e-mail: sayekti.octavian@uny.ac.id
}

\begin{abstract}
Abstrak
Penelitian ini bertujuan untuk meningkatkan motivasi belajar siswa pada aspek membaca permulaan di kelas 2 SD Negeri Pandeyan. Teknik yang digunakan untuk mengumpulkan data adalah pengamatan atau observasi, angket, wawancara, dan tes. Teknik analisis data yang digunakan dalam penelitian ini adalah teknik deskripsi komparatif. Peneliti membandingkan hasil sebelum penelitian dengan hasil pada akhir setiap siklus. Selain itu juga digunakan teknik analisis kritis dengan tujuan untuk mengungkapkan kelebihan dan kekurangan kinerja siswa dan guru selama proses kegiatan belajar mengajar. Hasil penelitian ini menunjukkan bahwa motivasi membaca permulaan siswa dalam pembelajaran tematik muatan bahasa Indonesia kelas 2 SD Negeri Pandeyan dapat ditingkatkan dengan menerapkan metode scramble. Peningkatan tersebut dapat dilihat sebagai berikut: (1) Pada siklus I meningkat menjadi 50\% serta 85\% siswa menyatakan senang mengikuti pembelajaran. antusiasme siswa dalam pembelajaran terjadi peningkatan pada siklus I 57\% menjadi $78 \%$ pada siklus II. Keaktifan siswa dalam apersepsi pada siklus I 50\% meningkat menjadi $78 \%$ pada siklus II. Selanjutnya untuk keaktifan siswa selama proses KBM pada siklus I 57\% meningkat menjadi $78 \%$ pada siklus II. Kemudian untuk keaktifan siswa dalam kegiatan tanya jawab pada siklus I $50 \%$ menjadi $64 \%$ pada siklus II.
\end{abstract}

Kata kunci: motivasi, membaca permulaan, metode scramble

\begin{abstract}
This study aims to increase students' motivation in the aspect of reading beginning in grade $2 S D$ Negeri Pandeyan. The techniques used to collect data are observation or observation, questionnaires, interviews, and tests. The data analysis technique used in this research is the comparative description technique. Researchers compared the results before the study with the results at the end of each cycle. In addition, critical analysis techniques are also used with the aim of revealing the strengths and weaknesses of student and teacher performance during the learning process. The results of this study indicate that the students' motivation to read the beginning of the thematic learning of Indonesian language content in grade 2 SD Negeri Pandeyan can be improved by applying the scramble method. This increase can be seen as follows: (1) In the first cycle it increased to 50\% and $85 \%$ of students said they were. happy to take part in learning. The enthusiasm of students in learning increased in cycle I 57\% to $78 \%$ in cycle II. The activeness of students in apperception in cycle I increased 50\% to $78 \%$ in cycle II. Furthermore, for student activeness during the teaching and learning process in cycle I 57\% increased to $78 \%$ in cycle II. Then for student activeness in question and answer activities in cycle I $50 \%$ to $64 \%$ in cycle II.
\end{abstract}

Keywords: motivation, early reading, Scramble methods

This is an open-access article under the CC-BY-SA license.

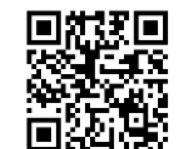

(c)

doi https://doi.org/10.21831/foundasia 


\section{PENDAHULUAN}

Bahasa Indonesia sebagai bahasa nasional wajib diajarkan di sekolah. Begitu pula yang terjadi di sekolah dasar. Siswa sekolah dasar hendaklah menguasai bahasa Indonesia. Apalagi di kurikulum yang digunakan saat ini yaitu Kurikulum 13, kedudukan bahasa Indonesia dalam pembelajaran menduduki posisi yang strategis. Bahasa Indonesia digunakan sebagai penghela mata pelajaran yang lain. Adapun pembelajaran bahasa Indonesia di sekolah dasar lebih ditekankan agar siswa mampu berkomunikasi menggunakan bahasa Indonesia dengan baik dan benar. Jika yang ditekankan adalah kemampuan siswa dalam berkomunikasi, maka siswa hendaklah menguasai pula empat aspek keterampilan dalam berbahasa. Keempat aspek keterampilan tersebut adalah menyimak, berbicara, membaca, dan menulis.

Dua aspek yaitu menyimak dan berbicara adalah aspek yang dikuasai oleh siswa sebelum mereka sekolah. Artinya dua aspek tersebut menjadi tanggung jawab orang tua sebagai pendidik siswa ketika di rumah. Adapun dua aspek yang lain yakni membaca dan menulis, akan didapatkan atau dipelajari siswa ketika mereka memasuki sekolah. Hal tersebut, bisa dimulai ketika siswa mulai memamsuki sekolah PAUD atau bahkan sekolah dasar. Namun keempat aspek keterampilan tersebut juga hendaklah diasah terus menerus di bangku persekolahan. Jangan sampai siswa tidak mengalami peningkatan dalam penguasaan keterampilan berbahasa tersebut.

Keterampilan membaca merupakan keterampilan ketiga yang akan dikuasai siswa. Seorang anak boleh diperkenalkan dengan kegaitan baca tulis sejak mereka duduk di bangku PAUD. Namun orang tua ataupun guru tidak boleh memaksa anaknya harus bisa membaca dan menulis pada bangku PAUD. Seorang anak dituntut untuk mampu membaca dan menulis saat mereka duduk di kelas 1 SD. Guru kelas 1 ini lah yang berkewajiban mengajarkan mereka baca tulis. Pembelajaran membaca menulis di SD kelas 1-2 dinamakan kegiatan membaca menulis permulaan.

Ada beragam hakikat membaca. Hal ini tentunya disesuaikan bagi subjeknya. Membaca untuk anak kelas 1 SD akan berbeda tuntutannya dengan anak kelas 2 atau bahkan kelas 5 SD. Membaca untuk kelas 1 dan 2 SD dimaknai merupakan tahap awal dalam belajar membaca yang difokuskan pada belajar mengenal simbol-simbol yang berkaitan dengan huruf sehingga menjadi pondasi agar anak bisa melanjutkan ke tahap membaca permulaan (Darwadi, 2002). Senada dengan hal tersebut Rahim (2007: 1) mengatakan bahwa membaca merupakan proses recording, decoding, dan meaning. Recording memiliki arti bahwa membaca adalah merekam atau menangkap bunyi atau simbol bahasa. Decoding memiliki makna proses penerjemahan rangkaian grafis ke dalam kata-kata. Adapun meaning memiliki makna pengartian atau pemaknaan bunyi-bunyi grafis tersebut. Meninjau pengertian membaca tersebut, memiliki arti bahwa siswa harus mampu melafalkan huruf, merangkai huruf menjadi kata, dan merangkai kata menjadi kalimat. Dalam hal ini, apabila siswa kurang berlatih atau jarang melakukan kegiatan membaca, maka ia akan kesulitan dalam melafalkan huruf atau merangkaikannya menjadi sebuah kata. Membaca merupakan kemampuan seseorang memahami apa yang tersirat dan yag tersurat (Küçükoĝlu, 2012: 709).

Keterampilan membaca bukanlah keterampilan yang secara instan dikuasai oleh siswa. Dalam hal ini siswa haruslah sering berlatih untuk memperdalam keterampilannya tersebut. Sekolah dan guru memiliki tanggung jawab yang besar akan hal ini. Guru harus mampu menggiring siswanya agar gemar membaca di tengah-tengah fenomena gadget yang saat ini melanda siswa. Sudah bukan rahasia lagi bahwa saat ini, para siswa lebih memilih berlama-lama di depan gadget daripada membaca buku. Mereka lebih asyik duduk berlama-lama dengan gadget daripada berlatih mengeja huruf. Hal ini berdampak pada kemampuan membaca permulaan yang mereka miliki. Padahal keterampilan membaca permulaan merupakan ujung tombak siswa dalam mengikuti pembelajaran di sekolah. Jika mereka tidak terampil membaca permulaan maka mereka akan kesulitan dalam mengikuti mata pelajaran lain. Mengingat keterampilan membaca merupakan keterampilan kunci yang digunakan siswa untuk mencari ilmu.

Permasalah yang diungkapkan pada paragraf di atas, juga terjadi di SD Negeri Pandeyan Yogyakarta. Berdasarkan hasil observasi, didapatkan informasi bahwa kemampuan membaca permulaan siswa kelas 2 SD N Pandeyan masih rendah. Hal tersebut ditunjukkan dari jumlah 14 siswa masih terdapat 7 siswa yang berada di bawah KKM. Permasalahan yang dihadapi siswa di SD 
Negeri Pandeyan antara lain, siswa malas berlatih membaca, tidak adanya dukungan orang tua di rumah, siswa mudah bosan jika membaca, sampai pada alasan siswa mudah pecah konsentrasinya jika melakukan kegiatan membaca. Adapun dari sisi guru, saat peneliti melakukan observasi belum terlihat guru menggunakan metode pembelajaran yang menarik. Pada saat itu, guru hanya melakukan kegiatan pembelajaran secara sederhana yakni siswa diminta membaca nyaring satu persatu atau yang lebih dikenal Shared Reading. Di sini guru harus berperan untuk meminimalisasi permasalahan pada keterampilan membaca tersebut. Jangan sampai keadaan ini berlarut dan akan memperparah kemampuan membaca permulaan yang dimiliki oleh siswa. Seperti yang dikutip dari penelitian Nell K. Duke and Meghan K. Block $(2012,66)$ salah satu keberhasilan dalam pembelajaran membaca adalah keahlian guru dalam memberikan kegiatan membaca yang menyenangkan dan bermakna.

Banyak cara yang bisa dilakukan oleh guru untuk menumbuhkan motivasi belajar siswa dan meningkatkan kemampuan siswa dalam membaca pemahaman. Penumbuhan motivasi merupakan langkah pertama yang harus dilakukan. Adanya motivasi akan menumbuhkan kecintaan anak untuk membaca. Motivasi merupakan usaha dan keinginan yang dimiliki seseorang untuk mencapai tujuan (Lahijan, 2016:11). Selain motivasi, langkah kedua yang perlu dilakukan adalah menggunakan pembelajaran yang menyenangkan. Hal ini bisa ditembuh melalui penggunaan model pembelajaran di dalam proses belajar mengajarnya. Penggunaan model pembelajaran yang tepat akan memudahkan guru dalam melakukan kegiatan belajar mengajar. Selain itu, adanya model pembelajaran juga akan membangkitkan motivasi siswa akan materi yang diajarkan. Siswa menjadi lebih aktif dan antusias. Hal ini akan mempermudah tercapainya tujuan pembelajaran.

Begitu pula dalam pembelajaran membaca permulaan. Beberapa model dan teknik pembelajaran bisa diterapkan dalam pembelajaran membaca permulaan. Misalnya Metode eja, metode SAS, metode gambar, metode Scramble dan lain-lain. Jika kegiatan membaca tanpa menerapkan model ataupun teknik yang tepat akan berdampak pada kemamampuan siswa dalam membaca. Alhasil siswa akan menjadi malas membaca, cepat bosan, bahkan kesusahan merangkai huruf ataupun kata. Alih-alih mampu memahami bacaan yang dituntut untuk siswa kelas 2 SD, merangkai huruf menjadi kata saja mereka belum mampu karena tidak adanya semangat dan motivasi membaca.

Dari berbagai metode dan teknik pembelajaran dalam membaca yang ditawarkan, penelitian ini akan lebih membahasa penggunaan metode pembelajaran scramble dalam pembelajaran membaca pemahaman. Metode scramble merupakan salah satu metode yang mengajak siswa bermain secara kreatif dalam menyusun huruf menjadi kata atau menyusun kata menjadi kalimat. Dikatakan oleh Kokom (2010: 84) metode scramble merupakan model pembelajaran yang mengajak siswa mencari suatu jawaban terhadap sebuah konsep secara kreatif dengan cara menyusun hurufhuruf yang disusun secara acak menjadi sebuah jawaban atau pasangan konsep.

Adapun jenis-jenis scramble ada beberapa jenis diantaranya: a) scramble kata adalah sebuah permainan menyusun huruf-huruf yang disusun acak menjadi sebuah kata b) scramble kalimat yaitu sebuah permainan menyusun kata yang disuus secara acak menjadi sebuah kalimat, c) scramble paragraf adalah sebuah permainan menyusun kalimat secara acak menjadi sebuah paragraf utuh, dan d) scramble wacana yaitu sebuah permainan menyusun wacana secara logis dan bermakna (Soeparno, 1988: 76). Sementara itu, sintak metode scramble adalah sebagai berikut : 1 . menyampaikan tujuan dan memotivasi siswa; 2. menyajikan Informasi; 3. mengorganisasi siswa ke dalam kelompok-kelompok belajar, selanjutnya membagikan kartu soal dan kartu jawaban pada kelompok; 4. mengerjakan kartu soal secara berkelompok; 5. memberikan penghargaan; dan 6. evaluasi (Artini, Vidya, I Wayan Sujana, I Km, Wiyasa, 2014).

Dari penjabaran tetang metode scramble di atas, metode ini dipilih sebagai salah satu metode alternatif yang bisa digunakan untuk mengatasi permasalahan terkait membaca permulaan. hal tersebut sejalan dengan penelitian Metta Ariyanto (2016: 239) yang berjudul Peningkatan Hasil Belajar IPA Materi Kenampakan Rupa Bumi Menggunakan Model Scramble. Penelitian tersebut menghasilkan kesimpulan bahwa model Scramble dapat meningkatkan hasil belajar siswa pada materi IPA SD. Selain penelitian di atas, penelitian milik Sudarmi dan Burhanudin (2017: 78) juga menyebutkan keefektifan model scramble jika digunakan dalam pembelajaran bahasa Jerman.

Metode scramble yang mengandung unsur permainan akan lebih membangkitkan motivasi anak dalam membaca. Hal tersebut dikarenakan dunia anak yang lekat akan dunia bermain. 
Berdasarkan latar belakang yang telah diuraikan dan hasil observasi yang telah peneliti lakukan di SD N Pandeyan Yogyakarta. Motivasi membaca permulaan siswa kelas 2 SD Pandeyan perlu ditingkatkan. Salah satu tujuan penelitian ini adalah untuk mengetahui peningkatkan motivasi siswa yaitu dengan menggunakan metode Scramble

\section{METODE PENELITIAN}

Penelitian ini merupakan penelitian tindakan kelas (PTK). Penelitian tindakan kelas merupakan penelitian tindakan yang dilakukan dengan tujuan untuk memperbaiki kualitas proses dan hasil belajar sekelompok peserta didik (Mulyasa, 2011: 10). Subjek penelitian tindakan ini adalah siswa kelas 2 SD Negeri Pandeyan tahun pelajaran 2018/2019. Siswa kelas 2 berjumlah 14 siswa. Adapun desain penelitian PTK adalah sebagai berikut: Dalam penelitian tindakan kelas (PTK), dilaksanakan dalam bentuk proses pengkajian berdaur yang terdiri atas empat tahap yaitu: Perencanaan (planning), tindakan (action), pengamatan (observation), dan reflection (Arikunto, 2006).

Data yang telah diperoleh di lapangan akan dikomparasikan oleh peneliti dengan menggunakan lembar observasi perilaku siswa serta angket, untuk melihat rasa senang dan antusiasme dalam pembelajaran serta keaktifan siswa selama pembelajaran berlangsung. Penitian ini menggunakan teknik perekaman yaitu dengan membuat catatan-catatan pada lembar pedoman observasi perilaku siswa berdasarkan perkembangan siswa setiap siklus.

Teknik yang digunakan untuk mengumpulkan data di atas meliputi pengamatan atau observasi, angket, wawancara atau diskusi, dan tes. Teknik analisis data yang digunakan dalam penelitian ini adalah teknik deskripsi komparatif. Teknik ini digunakan untuk membandingkan hasil antarsiklus.

\section{HASIL DAN PEMBAHASAN}

Berdasarkan penelitian yang telah dilakukan dapat dibuktikan bahwa penerapan metode scramble kalimat dapat mengoptimalkan motivasi siswa dalam membaca permulaan. Dari kegiatan siklus I dan siklus II dapat dideskripsikan sebagai berikut.

Motivasi membaca permulaan yang dimiliki siswa kelas 2 SD Negeri Pandeyan Yogyakarta mengalami peningkatan. Peningkatan tersebut dilihat dari hasil angket yang telah dilakukan siswa. Perkembangan motivasi siswa dalam membaca permulaan dapat dilihat dari tabel di bawah ini.

Tabel 1. Peningkatan Motivasi Belajar Siklus I ke Siklus II

\begin{tabular}{lllll}
\hline No. & Uraian Hasil & $\begin{array}{l}\text { Pra } \\
\text { siklus }\end{array}$ & Siklus I & Siklus II \\
\hline 1. & $\begin{array}{l}\text { Siswa senang dalam } \\
\text { pembelajaran }\end{array}$ & 7 & 10 & 12 \\
2 & $\begin{array}{l}\text { Siswa antusias } \\
3\end{array}$ & 5 & 8 & 11 \\
& $\begin{array}{l}\text { Siswa aktif } \\
\text { apersepsi }\end{array}$ & 6 & 7 & 11 \\
& $\quad$ proses KBM & 7 & 8 & 11 \\
& Tanya jawab & 4 & 7 & 9 \\
\hline
\end{tabular}

Pembahasan hasil penelitian yang meliputi motivasi siswa dalam pembelajaran membaca permulaan dengan menerapkan metode scramble kalimat di kelas 2 SD Negeri Pandeyan. Berdasarkan pengamatan tindakan dapat dinyatakan bahwa motivasi siswa dalam mengikuti pembelajaran mengalami peningkatan setelah diterapkannya metode scramble. Hal tersebut diperoleh dari hasil angket dan pengamatan yang dilakukan peneliti ketika proses pembelajaran berlangsung. Aspek motivasi yang diamati diantaranya rasa senang, antusiasme, dan keaktifan.

Pada pelaksanaan pembelajaran sebelum tindakan atau prasiklus motivasi siswa dalam mengikuti pembelajaran masih cukup rendah. Hal tersebut dapat dilihat bahwa hanya $50 \%$ atau 7 siswa yang menyatakan senang dalam pembelajaran membaca permulaan $71 \%$ atau 10 siswa menyatakan antusias dalam mengikuti pembelajaran, $36,7 \%$ atau 5 siswa menyatakan antusias dalam 
pembelajaran. Selanjutnya dari segi keaktifan dalam apersepsi, sebanyak 43,3\% atau 6 siswa yang aktif. Lalu di dalam dalam proses belajar mengajar, sebanyak 50\% atau 7 siswa. Sementara iti keaktifan dalam tanya jawab sebesar $23,3 \%$ atau 4 siswa.

Akan tetapi, setelah diterapkan metode scramble kalimat dalam pembelajaran membaca permulaan, motivasi siswa dalam pembelajaran tersebut mengalami peningkatan secara signifikan. Hal tersebut dapat dilihat bahwa 10 siswa atau $71 \%$ siswa yang menyatakan senang dalam pembelajaran membaca permulaan, 8 siswa atau $57 \%$ menyatakan antusias dalam mengikuti pembelajaran, 7 siswa atau 50\% aktif dalam apersepsi, 8 siswa atau 57\% aktif dalam KBM, serta 7 siswa atau $50 \%$ aktif dalam tanya jawab.

Setelah dilakukan refleksi tindakan siklus I dengan guru dan peneliti dengan adanya perbaikan pada siklus II akhirnya motivasi siswa dalam mengikuti pembelajaran membaca permulaan semakin meningkat. Hal tersebut dapat dilihat bahwa 12 siswa atau $85 \%$ secara keseluruhan menyatakan senang dalam pembelajaran serta 11 siswa atau $78 \%$ menyatakan antusias mengikuti pembelajaran. Selain itu, keaktifan siswa dalam apersepsi juga mengalami peningkatan menjadi 11 siswa atau 78\% siswa aktif dalam apersepsi, 11 siswa atau $78 \%$ aktif dalam KBM, dan 9 siswa atau $64 \%$ siswa aktif dalam tanya jawab.

Sebelum melaksanakan siklus I, peneliti melakukan survei awal pada tahap prasiklus untuk mengetahui pembelajaran di kelas 2 SD Negeri Pandeyan. Survei tersebut dilakukan untuk mengetahui permasalahan yang dijumpai di kelas. Berdasarkan hasil kegiatan survei ini peneliti menemukan bahwa motivasi siswa dalam pembelajaran membaca permulaan masih sangat rendah. Dari 14 siswa hanya 7 siswa yang terampil membaca. Kemudian peneliti dan guru kolaborator berupaya untuk mengatasi permasalahan tersebut dengan menerapkan metode scramble

Peneliti bersama guru menyusun rencana guna melaksanakan tindakan siklus I, siklus pertama merupakan tindakan awal untuk memperbaiki pembelajaran dan motivasi belajar anak dalam pembelajaran membaca permualaan dengan menerapkan metode scramble. Dalam siklus ini guru telah menerapkan metode scramble. Dari tindakan yang dilakukan pada siklus I ini dapat dideskripsikan hasil pembelajaran membaca permulaan. Dari deskripsi tersebut dapat diketahui terjadinya peningkatan terhadap motivasi siswa dalam mengikuti pembelajaran, namun masih banyak pula siswa yang kurang termotivasi. Selain itu, masih didapat kekurangan atau kelemahan dalam pelaksanaannya.

Kelemahan yang ada pada siklus I yaitu: a) siswa tidak mau berkelompok dengan teman yang tidak dia sukai, b) ada beberapa siswa yang tidak mau ketika diminta untuk membaca nyaring, c) pengeloaan kelas masih kesulitan.

Siklus II dilaksanakan untuk mengatasi kelemahan atau kekurangan yang terjadi pada siklus I. Pada siklus II ini guru dan peneliti berusaha memperkecil segala kelemahan dan kekurangan selama pelaksanaan pembelajaran. Berdasarkan pengamatan yang diperoleh pada siklus II ini terjadi kembali peningkatan motivasi siswa dalam mengikuti pembelajaran yang sangat signifikan. Hampir seluruh siswa aktif selama proses pembelajaran membaca permulaan berlangsung. Selain itu seluruh siswa menyatakan senang dan antusias mengikuti pembelajaran membaca permulaan dengan menerapkan metode scramble. Berdasarkan tindakan-tindakan yang telah diupayakan pada siklus I dan siklus II, guru berhasil melaksanakan pembelajaran yang mampu meningkatkan motivasi siswa dalam mengikuti pembelajaran membaca permulaan. Hal tersebut juga berdampak pada meningkatnya proses dan hasil kemampuan membaca permulaan dengan menerapkan metode scramble kalimat. Selain yang telah dirumuskan dalam pendahuluan mengenai peningkatan motivasi membaca permulaan. Penelitian ini juga meningkatkan kinerja guru dalam melaksanakan pembelajaran yang efektif dan menarik. Ketercapaiannya peningkatan motivasi siswa dalam mengikuti pembelajaran dapat dilihat dengan indikator-indikator sebagai berikut.

Setelah dilakukannya tindakan, yaitu penerapan metode scramble kalimat dalam pembelajaran membaca permulaan, siswa tertarik untuk mengikuti pembelajaran. Siswa merasa senang dan antusias mengikuti pembelajaran dari awal hingga akhir. Selain itu siswa juga mulai aktif dari siklus ke siklus.

Berdasarkan hasil angket yang diperoleh, banyak siswa yang menyatakan senang dan antusias mengikuti pembelajaran membaca permulaan. Pada siklus I sebesar $71 \%$ siswa menyatakan senang mengikuti pembelajaran dan sebesar $57 \%$ siswa menyatakan antusias dalam mengikuti 
pembelajaran membaca permulaan. Selain itu, peningkatan juga terjadi pada siklus II yaitu sebesar $85 \%$ siswa menyatakan senang mengikuti pembelajaran dan sebesar $78 \%$ siswa menyatakan antusias dalam mengikuti pembelajaran membaca permulaan. Pembelajaran dikemas dengan menarik dan juga menggunakan permainan scramble kalimat sehingga menarik pula bagi siswa untuk termotivasi dalam mengikuti pembelajaran.

Penggunaan permainan di dalam pembelajaran akan merangsang motivasi anak untuk belajar membaca. Apalagi di kelas 2 SD Negeri Pandeyan ini, rata-rata siswanya memiliki gaya belajar kinestitek sehingga akan sangat sesuai jika menyisipkan permainan di dalam pembelajarannya. Anak yang memiliki gaya belajar kinestetik akan tetap aktif bergerak namun sebenarnya dia juga belajar membaca. Selain itu, pembelajaran yang berkelompok juga akan membuat siswa yang masih kurang dalam hal keterampilan membaca akan dibantu oleh siswa lain. Hal ini senada dengan penelitian yang dilakukan Primadiati \& Djukri (2017, p. 56) bahwa pembelajaran dengan menggunakan model collaborative learning dapat meningkatkan motivasi belajar. Karena saat pembelajaran berlangsung akan terdapat hubungan saling belajar siswa sehingga membuat siswa yang kurang memahami pembelajaran tersebut terdorong untuk meminta bantuan teman dalam kelompoknya. Situasi ini terjadi juga di dalam pembelajaran membaca permulaan dengan menggunakan metode scramble kalimat. Karena memang metode ini didesain dengan melibatkan pembelajaran berkelompok.

Setelah dilakukan tindakan dengan menerapkan metode scramble, siswa mulai senang dan antusias mengikuti pembelajaran membaca permulaan. Berdasarkan pengamatan yang dilakukan peneliti, keaktifan siswa dalam siklus I dideskripsikan sebagai berikut, 7 siswa atau 50\% aktif dalam apersepsi, 8 siswa atau 57\% aktif dalam KBM, serta 7 siswa atau 50\% aktif dalam tanya jawab. Sedangkan pada siklus II, 11 siswa atau 78\% siswa aktif dalam apersepsi, 11 siswa atau $78 \%$ aktif dalam KBM, dan 9 siswa atau 64\% siswa aktif dalam tanya jawab.

Setelah diterapkan metode scramble kalimat siswa terlihat lebih tertarik ketika diminta mengurutkan kata menjadi kalimat. Hal itu akan berdampak kepada motivasi belajar membaca yang siswa alami. Mau tidak mau sebelum mereka mengurutkan menjadi kalimat, mereka harus mampu membaca kata per kata lalu menyusunnya menjadi kalimat. Hanya ada beberapa siswa yang kurang tertarik dengan pembelajaran saat itu. Hal ini ditunjukkan dengan perilaku mereka yang masih pasif dan kurang merespon pembelajaran membaca permulaan pada siklus I.

Pembelajaran membaca menggunakan metode scramble kalimat ini juga didesain dengan berkelompok, sehingga siswa yang aktif akan mempengaruhi siswa lain. Dalam sebuah kelompok ada siswa yang lebih unggu disbanding temannya, kemudian dia secara tidak langsung memberikan iklim belajar positif pada temannya. Siswa yang lebih unggul ini sengaja ditempatkan di kelompok berbeda agar mampu membantu siswa lain yang keterampilan membacanya belum lancar. Hal ini menyebabkan siswa yang semula pasif menjadi terlibat aktif dalam pembelajaran.

Hasil wawancara menunjukkan bahwa hampir semua siswa merasa asyik ketika mengikuti proses pembelajaran membaca permulaan dengan menerapkan metode scramble kalimat. Mereka menyatakan bahwa belajar membaca menggunakan metode scramble kalimat tidak membosankan karena pembelajaran dilakukan sambal bermain, berkompetisi, dan bekerjasama dengan teman dalam kelompok. Namun, ada juga siswa yang menganggap pembelajaran membaca permulaan dengan menerapkan metode scramble sama dengan pembelajaran sebelumnya.

Pendidikan di sekolah idealnya mampu mengembangkan kemampuan siswa agar seluruh fungsi pendidikan dapat tercapai (Purwaningsih \& Herwin, 2020). Temuan penelitian ini memberikan informasi bahwa dalam membangkitkan motivasi siswa ketika pembelajaran sangat ditentukan oleh peran guru. Hal ini sejalan dengan penelitian yang dilakukan oleh Patandung (2017, p. 16) Guru sangat memegang peranan penting dalam keberhasilan siswa. Selain sebagai motivator, guru juga mampu menjadi inspiratory. Dalam hal ini juga memberikan pengetahuan bahwa di dalam pembelajaran diperlukan guru yang kreatif. Kreatif dalam hal mendeasain pembelajaran yang membangkitkan motivasi siswa. Hal itu bisa dilakukan salah satunya dengan menggunakan metode dan model pembelajaran. Ini yang disebut sebagai motivasi ekstrinsik. Guru, juga harus mampu memebrikan motvasi intrinsik kepada siswanya karena motivasi itulah yang mampu memberi dorongan terbesar bagi pengembangan potensi siswa menjadi sebuah kemampuan (Syarif, 2017: p. 
247). Selain itu idealnya pengembangan siswa tidak hanya pada tataran akademik namun menyentuh pada kecakapan personal dan kecakapan sosial (Herwin, 2019).

Pelaksanaan pembelajaran membaca permulaan dengan menerapkan metode scramble tidak lepas dari kendala yang menghambat proses pembelajaran antara lain: a) Guru dan siswa belum terbiasa menerapkan metode scramble kalimat dalam pembelajaran. Hal ini tampak pada pembelajaran yang terlihat kaku pada siklus I dan guru terkadang lupa dengan prosedur yang harus diterapkan, sehingga guru sering melihat RPP ketika mengajar, b) masih ada beberapa siswa yang kurang bisa diatur. Masih ada yang mengganggu teman dan mberbuat gaduh di kelas, c) beberapa siswa tidak mau bergabung dengan teman kelompoknya, c) siswa masih kebingungan menyusun kata menjadi kalimat. Kendala-kendala tersebut dianalisis oleh kolaborator dan guru kemudian dilakukan perbaikan pada siklus berikutnya yaitu siklus II.

Ada beberapa cara untuk mengatasi kendala yang menghambat dalam pelaksanaan pembelajaran maka guru berupaya mengatasi kendala tersebut dengan beberapa solusi yang telah diterapkan pada siklus II, antara lain: a) Guru sudah mau berusaha mempersiapkan diri dengan mempelajari RPP terlebih dahulu sebelum mengajar dengan baik terutama dalam penerapan prosedur permainan tradisional, b) guru berusaha memberikan penjelasan kepada siswa agar tidak mengganggu teman yang lain, c) guru memberikan penjelasan, bahwa kalimat itu diawali dengan huruf kapital, sehingga siswa diminta meletakkan kata yang ada huruf kapitalnya di awal.

\section{SIMPULAN}

Berdasarkan pembahasan, motivasi membaca permulaan pada pembelajaran tematik kelas 2 SD Negeri Pandeyan dapat ditingkatkan dengan menerapkan metode scramble. Peningkatan tersebut dapat dilihat pada motivasi siswa dalam mengikuti pembelajaran mengalami peningkatan. Hal tersebut dapat dilihat dari hasil pengamatan dan angket yang diberikan kepada siswa. Pada prasiklus hanya 50\% siswa yang menyatakan senang mengikuti pembelajaran, namun setelah diterapkannya metode scramble menjadi $71 \%$ siswa pada siklus I, serta $85 \%$ siswa menyatakan senang mengikuti pembelajaran. Hal senada juga terjadi pada antusiasme siswa dalam pembelajaran. Pada prasiklus hanya $36,7 \%$ siswa yang menyatakan antusias mengikuti pembelajaran, namun terjadi peningkatan menjadi $57 \%$ pada siklus I, serta $78 \%$ pada siklus II. Keaktifan siswa selama pembelajaran membaca permulaan juga mengalami peningkatan. Berdasarkan pengamatan dapat ditunjukkan bahwa keaktifan siswa dalam apersepsi yang semula 43,3\% siswa menjadi 50\% siswa pada siklus I dan meningkat menjadi $78 \%$ pada siklus II. Selanjutnya untuk keaktifan siswa selama proses KBM yang semula 50\% siswa pada prasiklus menjadi 57\% siswa pada siklus I dan meningkat menjadi $78 \%$ pada siklus II. Kemudian untuk keaktifan siswa dalam kegiatan tanya jawab yang sebelumnya hanya $23,3 \%$ siswa menjadi $50 \%$ siswa pada siklus I dan $64 \%$ pada siklus II.

\section{DAFTAR PUSTAKA}

Arikunto, S. (2006). Dasar-Dasar Penelitian Tindakan Kelas. Jakarta: Bumi Aksara.

Ariyanto, M. (2016). Peningkatan Hasil Belajar IPA Materi Kenampakan Muka Bumi Menggunakan Model Scramble. Jurnal Profesi Pendidikan Dasar. Vol. 3. No 2, 134-140.

Artini, Vidya, I Wayan Sujana, I Km, Wiyasa. (2014). Pengaruh Model Pembelajaran Scramble Berbantuan Media Semi Konkret Terhadap Hasil Belajar IPS Siswa Kelas V SD Gugus Kapten Kompiang Sujana. Jurnal Mimbar PGSD Undikhsa. Vol 2. No. 1.

Dawadi. (2002). Langkah-Langkah Keterampilan Proses. Jakarta: Gramedia.

Herwin, H. (2019). Evaluasi Program Pembelajaran IPS di Sekolah Dasar Negeri 126 Lagoe. DIDAKTIKA: Jurnal Pendidikan Sekolah Dasar, Vol. 2, No.2, 41-48.

Küçükoĝlu, H. (2012). Improving Reading Skills Through Effective Reading. Procedia - Social and Behavioral Sciences Vol. 70, $709-714$.

Komalasari, K. (2010). Pembelajaran Kontekstual (Konsep dan aplikasi). Bandung: Refika Aditama. Lahijan B,. (2016). The Impact of Motivation on English Language. Learning International Journal of Research in English Education. Vol. 1. No 1, 11-15.

Mulyasa. (2011). Praktik Penelitian Tindakan Kelas. Bandung: PT Remaja Rosdakarya. 
Nell K. Duke \& Meghan K. Block. (2012). Improving Reading in the Primary Grades. The Future of Children, FALL. Vol. 22, No. 2, 55-72.

Patandung, Y. 2017. Pengaruh Model Discovery Learning Terhadap Peningkatan Motivasi Belajar IPA Siswa. Journal of Educational Science and Technology. Vol. 3. No. 1, 1-16.

Primadiniati, I \& D. Djukri. 2017. Pengaruh Model Collaborative Learning terhadap Peningkatan Motivasi dan Hasil Belajar IPA Siswa Kelas IV SD. Jurnal Prima Edukasia. Vol. 5. No. 1, 4757.

Purwaningsih, A. Y., \& Herwin, H. (2020). Pengaruh regulasi diri dan kedisiplinan terhadap kemandirian belajar siswa di sekolah dasar. Jurnal Penelitian Ilmu Pendidikan, Vol. 13, No. $1,22-30$.

Rahim, F. (2007). Pengajaran Membaca di Sekolah Dasar. Jakarta: Bumi Aksara

Soeparno. (1988). Metode Pembelajaran Bahasa. Bandung: Rosda Karya.

Sudarmi \& Burhanudin. (2017). Keefektifan Model Pembelajaran Kooperatif Tipe Scramble dalam Keterampilan Menulis Kalimat Bahasa Jerman Siswa Kelas XI SMA Negeri 11 Makasar. Jurnal Eralingua. Vol. 1. No. 1, 72-79.

Syarif, I. (2012). Pengaruh Model Blended Learning Terhadap Motivasi dan Prestasi Belajar Siswa SMK. Jurnal Vokasi. Vol. 2. No. 2, 238-250. 